\title{
METANÁLISE SOBRE O USO DA FERTILIZAÇÃO NITROGENADA EM PENNISETUM PURPUREUM
}

\author{
AUTOR: LÁZARO TIAGO DE OLIVEIRA \\ CO-AUTOR/ORIENTADOR: BRUNO BORGES DEMINICIS
}

\begin{abstract}
Resumo: O presente trabalho empregou um estudo metanalítico para sumarizar e analisar dados sobre adubação nitrogenada em Capim elefante (Pennisetum purpureum). Foram selecionados trabalhos de pesquisa realizados no Brasil nos últimos 10 anos, incluindo apenas artigos científicos e dissertações/ teses. Com base nos dados contidos nesses trabalhos, foi calculado o incremento relativo de matéria seca e de proteína bruta em relação ao tratamento controle (ausência de adubação nitrogenada) e a eficiência da utilização do nitrogênio na produção de matéria seca e proteína bruta. Os dados obtidos foram submetidos à análise de variância para efeito linear e quadrático em cada uma das variáveis, no caso de significância, foi realizada análise de regressão. A fertilização nitrogenada em capim elefante acima de $1000 \mathrm{~kg}$ de Nitrogênio/ha há comprometimento da eficiência da produção de matéria seca, com vistas a eficiência na produção de proteína bruta, acima de $500 \mathrm{~kg}$ de nitrogênio ocorre drástica redução da eficiência da produção de proteína bruta pelo capim elefante.
\end{abstract}

Palavras-chave: Metanálise, eficiência da adubação, forrageiras tropicais, nitrogênio. 